\title{
Sekolah Keluarga: Menciptakan Lingkungan Sosial untuk Membangun Empati dan Kreativitas Anak Usia Dini
}

\author{
Sjafiatul Mardliyah ${ }^{\circledR}$, Wiwin Yulianingsih², Lestari Surya Rachman Putri ${ }^{3}$ \\ Pendidikan Luar Sekolah, Universitas Negeri Surabaya \\ DOI: $10.31004 /$ obsesi.v5i1.665
}

\begin{abstract}
Abstrak
Perkembangan empati dan kreativitas pada anak usia dini perlu mendapat perhatian. Hal ini memerlukan kerjasama antara sekolah, orangtua dan anak didik. Tujuan penelitian adalah untuk menggambarkan bentuk dan upaya KB Salam mewujudkan interkonektivitas tiga elemen tersebut dan berdampak positif terhadap tumbuhnya kreativitas dan empati pada anak usia dini. Metode penelitian menggunakan pendekatan kualitatif etnografi untuk mengungkap fakta tentang pembelajaran di KB Salam dan berdampak pada perkembangan empati dan kreaitivitas anak usia dini. Subjek penelitian adalah pendiri, pengelola, fasilitator, dan orangtua di KB Salam. Tehnik pengumpulan adalah wawancara, observasi dan dokumentasi. Hasil penelitian menunjukkan bahwa KB Salam mengembangkan kurikulum pembelajaran berdimensi lokal berdasarkan filosofi dan konteks sosial budaya. Pembelajaran di KB Salam menciptakan habitus komunitas belajar dengan cara pendayagunaan metode pembelajaran yang bersinergi dengan interaksi sosial keseharian antara guru, anak didik dan orangtua. Keterlibatan orangtua dalam proses pembelajaran di sekolah untuk mengembangkan empati dan kreativitas pada anak usia dini dilahirkan oleh lingkungan sosial yang disebut sekolah keluarga.
\end{abstract}

Kata Kunci: sekolah; keluarga; kreativitas; empati.

\begin{abstract}
The development of empathy and creativity in early childhood needs attention. This requires cooperation between schools, parents, and students. The purpose of this research is to describe the form and effort of KB Salam to realize the interconnectivity of these three elements and have a positive impact on the growth of creativity and empathy in early childhood. The research method uses a qualitative ethnographic approach to uncover facts about learning in Salam and has an impact on the development of empathy and early childhood creativity. The research subjects were founders, managers, facilitators, and parents at KB Salam. Collection techniques are interviews, observation, and documentation. The results showed that KB Salam developed a curriculum of learning with local dimensions based on the philosophy and sociocultural context. Learning at KB Salam creates a habitus of the learning community by utilizing learning methods that synergize with daily social interactions between teachers, students, and parents. Parental involvement in the learning process in schools to develop empathy and creativity in early childhood is born by a social environment called family school.
\end{abstract}

Keyword: school; family; creativity; empathy.

Copyright (c) 2020 Sjafiatul Mardliyah, Wiwin Yulianingsih, Lestari Surya Rachman Putri

$\triangle$ Corresponding author :

Email Address : sjafiatulmardliyah@unesa.ac.id (Surabaya, Jawa Timur)

Received 14 July 2020, Accepted 17 July 2020, Published 26 July 2020 


\section{PENDAHULUAN}

Undang-Undang Sisdiknas No 20 Tahun 2003 pasal 28 ayat 1 tentang Pendidikan Anak Usia Dini berbunyi bahwa Pendidikan Anak Usia Dini diselenggarakan sebelum jenjang pendidikan dasar. Lebih lanjut pada Bab I pasal 1 ayat 14 ditegaskan bahwa Pendidikan Anak Usia Dini adalah suatu upaya pembinaan yang ditujukan kepada anak sejak lahir sampai dengan usia enam tahun yang dilakukan melalui pemberian rangsangan pendidikan untuk membantu pertumbuhan dan perkembangan jasmani dan rohani agar anak memiliki kesiapan dalam memasuki pendidikan lebih lanjut (JDIH BPK RI, 2003). Salah satu bentuk pertumbuhan dan perkembangan jasmani dan rohani sebagaimana dimaksudkan pada pasal tersebut adalah kreativitas dan empati.

Kelompok Bermain di Salam didirikan berdasarkan hasil musyawarah orangtua murid dan kebutuhan masyarakat sekitar. Proses pembelajaran di Salam memegang teguh prinsip kerjasama antara siswa, orangtua, dan sekolah untuk melahirkan ekosistem belajar untuk bersama-sama mempelajari pangan, kesehatan, lingkungan, dan sosial budaya. Tujuannya adalah agar sejak awal masa pendidikan siswa di Salam mampu mengenali masalah hingga menciptakan solusi. Hal ini mendorong pentingnya melahirkan aspek kreativitas dan empati siswa sejak usia dini selain aspek perkembangan lainnya.

Kreativitas adalah hasil kerja kognitif yang melibatkan proses mental berupa motivasi dan komitmen untuk menunjukkan kualitas individu (Wright, 2010:3). Kreativitas melibatkan unsur imajinatif untuk membuka pintu gerbang dunia yang lebih baik. Kreativitas pada anak usia dini memberikan ruang agar terlibat dengan dunia sosial sehingga terjadi koneksi imajinatif antara pengalaman masa lalu, sekarang dan yang akan datang (Prentice, $2000: 145$ ). Sayangnya unsur kreativitas ini dianggap kurang penting dibandingkan dengan membaca, menulis dan pekerjaan rumah (reading, writing and number work) yang hingga saat ini masih banyak digunakan dalam pembelajaran di kelas, tidak terkecuali pada pembelajaran anak usia dini.

Empati adalah proses sosio-emosional dasar dari perkembangan manusia yang melibatkan kemampuan untuk memahami keadaan emosional dan berbagi dengan orang lain. Proses ini menentukan keberhasilan fungsi sosial dan mental seseorang (Richaud, Lemons, Mesurado, \& Oros, 2017: 1). Perkembangan empati penting untuk membentuk kompetensi sosial, keterkaitan sosial, dan perilaku prososial. Meningkatkan keterampilan ini cenderung meningkatkan fungsi sosial anak-anak (Maynard, Monk, \& Booker, 2011 : 166). Peran orang tua dan guru diperlukan untuk mendesain hubungan teman sebaya yang berdampak positif untuk meningkatkan perkembangan sosial dan emosional anak usia dini (Ramadhani \& Fauziah, 2020: 1011).

Menumbuhkan kreativitas dan empati pada anak usia dini membutuhkan pendekatan pembelajaran yang harus memperhatikan lingkungan belajar yang aman bagi anak-anak, sehat, memelihara demokrasi, toleransi, anti-intimidasi dan diskriminasi jenis kelamin, agama, maupun etnis (Subkhan, 2013: 1). Usaha ini membutuhkan jalur pendidikan prasekolah untuk membantu pertumbuhan dan perkembangan jasmani dan rohani anak di luar lingkungan keluarga sebelum memasuki pendidikan dasar (Rachmawati \& Kurniati, 2010: 28). Anak usia dini membutuhkan perpaduan pembelajaran sains, seni, bahasa, agama, dan IT secara terintegratif untuk mengembangkan kreativitas (Astuti \& Aziz, 2019: 294). Beberapa hasil penelitian tindakan kelas mampu membuktikan bahwa: metode STEAM pada pembelajaran mampu meningkatkan kreativitas anak usia dini dalam cara berfikir (Wahyuningsih, Pudyaningtyas, Hafidah, Syamsuddin, Nurjanah, \& Rasmani, 2019: 295); penggunaan video gerak dan lagu neurokinestetik juga mampu menumbuhkan kreativitas anak usia dini dari pada menggunakan video konvensional (Prahesti, Taulany, \& Dewi, 2019: 162); kegiatan menganyam dengan menggunakan origami terbukti mampu meningkatkan kreativitas pada anak usia dini (Sari \& Nofriyanti, 2019: 146); penggunaan media pembelajaran, yaitu magic puffer ball, berpengaruh pada kreativitas anak usia dini. Kreativitas membantu anak untuk menemukan ide-ide dan berimajinasi untuk membuat sesuatu hal yang baru (Debeturu \& Wijayaningsih, 2019: 233). 
Sementara itu beberapa hasil penelitian menunjukkan bahwa menumbuhkan empati pada anak usia dini dapat dijelaskan dari hasil penelitian berikut ini. Keterampilan sosial anak usia dini terdiri dari empat aspek yaitu anak mampu bekerjasama, kontrol diri, berkomunikasi dan bersikap empati dapat terwujud dalam kegiatan Tari Saman yang digunakan dalam pembelajaran. (Sari, Yetti, \& Supena, 2019: 1). Kemampuan anak usia dini untuk membina konsep diri dan mengendalikan emosi dipengaruhi oleh keterlibatan dan peran ibu sebagai pendidik utama dan pertama (Robbiyah, Ekasari, \& Witarsa, 2018: 76). Hasil penelitian PTK membuktikan bahwa permainan kolaboratif mampu mengembangkan kemampuan sosial emosional anak usia dini (Ananda \& Fadhilaturrahmi, 2018: 20); dan menjelaskan adanya peningkatan perkembangan sosial dengan menggunakan metode proyek (Izza, 2020: 951). Hasil penelitian korelasional menunjukkan hubungan yang signifikan antara antara game online yang digunakan sebagai media pembelajaran oleh guru dengan perkembangan emosional anak usia dini (Sari \& Nurjanah, 2020: 994). Kemampuan sosial individu tidak dimiliki secara alami. Sehingga bagi anak usia dini perlu dikembangkan melalui kegiatan dalam pembelajaran, salah satunya adalah bermain kartu estafet oleh guru (Perdina, Safrina, \& Sumadi, 2019: 440). Guru yang menggunakan media pembelajaran big book berbasis cerita rakyat terbukti lebih efektif untuk meningkatkan karakter toleransi anak usia 5-6 tahun dibandingkan dengan menggunakan media buku biasa maupun pembelajaran konvensional (Purnamasari \& Wuryandani, 2019: 90).

Selain jalur pendidikan pra sekolah, maka unsur keluarga sebagai pendidik pertama dan utama tidak bisa diabaikan. Keluarga adalah sekolah pertama pembentukan karakter (Dimerman, 2009: 55-60). Artinya, keluarga adalah tempat sosialisasi pertama bagi anak dan bertugas menanamkan nilai-nilai moral, keagamaan, dan sosial. Karakter anak, terutama kreativitas dan empati, berkembang secara optimal jika keluarga menerapkan pola asuh demokratis. Kondisi ini menuntut keluarga memenuhi fungsi nurturant caregiving, material careiving, social caregiving, dan didactic caregiving serta bertanggungjawab terhadap kegiatan pembelajaran anak saat berada di luar sekolah. Indonesia yang memiliki aneka ragam adat istiadat dan kebudayaan, juga berkontribusi dalam pendidikan anak (Rozana, Wahid, \& Muali, 2018: 16). Penelitian yang dilakukan di Suku Bajo, menjelaskan bahwa kebudayaan masyarakat pada kehidupan Suku Bajo, mampu mendorong pengembangan ketrampilan sosial anak. Nilai-nilai itu adalah bekerjasama, belajar bersama, bermain bersama, saling melindungi, tolong menolong diajarkan oleh keluarga kepada anak-anak mereka sejak usia dini (Machmud, Alim, \& Ulviya, 2020 : 787). Sehingga ketika anak melakukan kegiatan belajar bersama pendidik (guru) di sekolah dapat terintegrasi dengan pendidikan keluarga (Desyanty, 2016 : 69).

Di sisi lain, penting juga mempertimbangkan bahwa status ekonomi orang tua berkorelasi dengan child rearing untuk mendukung tumbuh kembang anak usia dini (Garzia, Yufiarti, \& Hartati, 2019: 470). Hasil penelitian ini berkorelasi dengan hasil penelitian Putro yang menunjukkan bahwa terdapat hubungan positif antara pola asuh dan interaksi antar teman sebaya baik terpisah maupun simultan terhadap kecerdasan emosional anak (Putro, 2015: 97). Dengan demikian, keterlibatan orangtua sangat dibutuhkan agar perilaku sosial negatif, seperti bullying, dapat dikendalikan dan anak memiliki regulasi diri yang tinggi agar sesuai tumbuh kembang anak usia dini (Putri, Yetti, \& Hartati, 2020: 715). Untuk mendorong hubungan harmonis antara keluarga dan sekolah, maka dukungan keluarga dan ketelibatannya dalam kegiatan di sekolah sangat penting. Pendidikan anak usia dini membutuhkan pendekatan holistik integratif yang menempatkan dukungan keluarga sebagai penyelenggara pendidikan di rumah dan berpartisipasi aktif dalam kegiatan di sekolah (Ulfah M. , 2019: 10).

Anak usia dini menghabiskan waktu sebesar dua puluh persen di sekolah dan delapan puluh persen di lingkungan keluarga dan masyarakat (Wiyani, 2016: 67), mendukung hasil studi yang dilakukan di Inggris, Finlandia, Spanyol dan Swiss yang menjelaskan peran penting bagi guru untuk memahami dan melibatkan keluarga dan masyarakat. Belgia mengembangkan Parent Teacher Communications Competencies (PTCC) sebagai alat ukur 
keaktifan guru berinteraksi dengan keluarga (Epstein, 2018: 11). Dengan demikian diperlukan desain proses pembelajaran yang melibatkan orangtua membantu guru mengembangkan perilaku dan sikap siswa (Aasheim, Drugli, Reedtz, Handegard, \& Martinussen, 2018: 1064). Penguatan keluarga melalui parenting diperlukan untuk untuk pengembangan anak, metode pengasuhan, dan pola komunikasi keluarga (Akhyadi \& Mulyono, 2019: 8). Hasil penelitian Arifiyanti menjelaskan bahwa bentuk kerjasama antara sekolah dan orangtua dilakukan dengan menciptakan iklim sekolah yang nyaman, melakukan komunikasi awal dengan orangtua, dan memberikan kesempatan bagi orangtua untuk terlibat dalam pembelajaran anak (Arifiyanti, 2015: 10).

Stimulasi guru melalui pemanfaatan media pembelajaran dan pola asuh orangtua adalah kombinasi yang tepat untul meningkatkan kemampuan sosial-emosional pada anak usia dini (Tatminingsih, 2019: 484). Keterlibatan orang tua dalam mendidik anak usia dini meliputi faktor status sosial, faktor bentuk keluarga, faktor tahap perkembangan keluarga, dan faktor model peran keluarga. Sementara sekolah memberikan fasilitas kepada keluarga untuk mengikuti kegiatan: parenting education, informasi tentang pendidikan, perkembangan, dan kesehatan anak, pembelajaran di rumah, pertunjukan penampilan anak,rekreasi,bekerjasama dengan komunitas masyarakat dalam puncak tema, kunjungan ke rumah oleh guru, dan partisipasi pada kegiatan sekolah (Irma, Nisa, \& Sururiyah, 2019: 214). Sekolah perlu melibatkan kegiatan parenting dalam proses pembelajaran di sekolah baik di kelas maupun luar kelas, agar orangtua dan guru bersama memantau perkembangan anak usia dini (Mardliyah, Siahaan, \& Budirahayu, 2020: 892).

Interkonektivas sekolah, keluarga, masyarakat untuk mendukung sistem pembelajaran perlu memperhatikan aspek sistem sosial. Sistem sosial ini bertujuan untuk membentuk ekologi dan memberi dampak edukasi keluarga dan interaksi lingkungan untuk mengembangkan karakteristik anak didik. Di sekolah, guru harus dapat merangsang minat dan rasa ingin tahun anak didik, dengan melibatkannya dalam proses pembelajaran secara aktif (Rahman, 2009: 46). Salah satu upaya untuk meningkatkan kreativitas anak usia dini, dengan menggunakan strategi pembelajaran terpadu berbasis kecerdasan jamak (Asmawati, 2017: 145). Guru juga dapat menggunakan bahan sisa (Elvida, 2012: 33) dan melukis menggunakan sikat gigi (Martinis, 2012: 11) dalam pembelajaran untuk meningkatkan kreativitas anak usia dini Sementara itu, salah satu upaya untuk mengembangkan empati anak adalah melalui mendongeng (Iis, 2012: 11).

Peneliti menemukan fenomena menarik tentang hubungan keluarga dan sekolah di Kelompok Bermain Sanggar Anak Alam (Salam) yang berlokasi di Nitiprayan Kasihan Bantul Yogyakarta. Jika dibandingkan dengan hasil penelitian yang dijelaskan sebelumnya, nampak bahwa Salam adalah sekolah keluarga (family school) yang mampu mengintegrasikan pendidikan keluarga dan sekolah dengan menciptakan lingkungan sosial yang diperlukan agar proses belajar berjalan dengan baik. Meminjam istilah Spradley, Salam mampu menempatkan konsep parenting sebagai culture-bound dalam proses belajar yang sudah berjalan selama 20 tahun (Spradley, 2007: 17). Proses pembelajaran di Salam, melibatkan orang tua dalam arti bahwa pengaturan kelas dilakukan berdasarkan kompromi orang tua. Hal ini berbeda dari beberapa hasil penelitian sebelumnya yang menitikberatkan peran guru bersifat dominan dan menitikberatkan pada konsep pembelajaran dengan menggunakan penelitian tindakan kelas. Penelitian ini bertujuan untuk menggambarkan bentuk dan upaya Salam mewujudkan sekolah keluarga yang berdampak positif terhadap tumbuhnya kreativitas dan empati pada anak usia dini. Urgensi penelitian ini adalah memberikan pemahaman sinergitas antara pola asuh orangtua dan sekolah yang terlibat dalam setiap proses pembelajaran untuk mengembangkan empati dan kreativitas anak usia dini

\section{METODOLOGI}

Penelitian ini menggunakan pendekatan kualitatif etnografis dengan tujuan untuk memperhatikan makna-makna tindakan dari kejadian yang menimpa orang atau kelompok masyarakat yang ingin dipahami. Deskripsi etnografi standar ala Spradley digunakan untuk 
memasukkan konsep dan makna ke dalam deskripsi dan memberi suatu pengertian mendalam mengenai sekolah keluarga yang dikonstruksi oleh Salam dan berdampak pada perkembangan empati dan kreaitivitas anak usia dini (Spradley, 2007: 17).

Subjek penelitian adalah pendiri, pengelola, fasilitator (guru), orangtua di KB Salam. Tehnik pengumpulan data melalui wawancara mendalam menjadi prioritas, sementara observasi dan dokumentasi menjadi pelengkapnya. Hasil wawancara tentang sekolah keluarga dan perkembangan empati dan kreativitas anak usia dini ditulis dalam sebagai hasil dari transkrip wawancara.

Teknik analisa data dilakukan melalui tahapan reduksi data, sajian data, dan verifikasi. Reduksi data, sajian data, dan verifikasi adalah tahapan yang dilakukan dalam tehnik analisa data. Proses analisa dengan tiga komponen tersebut saling menjalin dan dilakukan secara terus menerus di dalam proses pelaksanaan pengumpulan data dalam model analisis jalinan seperti digambarkan pada skema dibawah ini (Sutopo, 2001: 57).

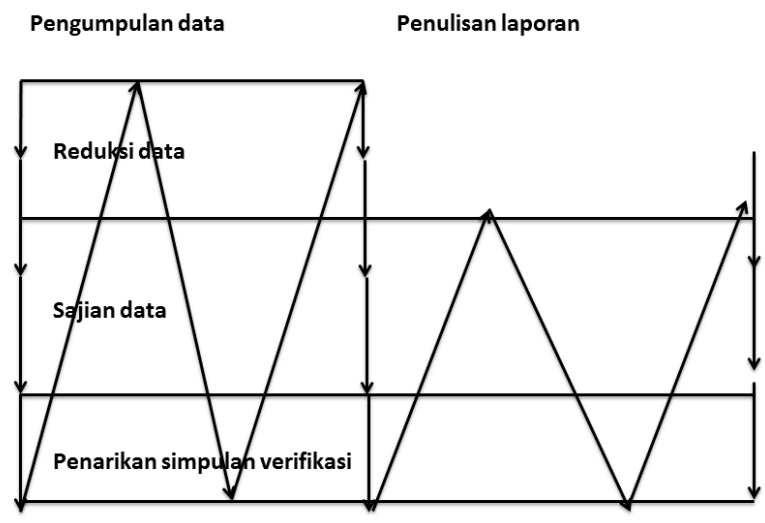

Gambar 1: Model Analisis Jalinan.

Gambar 1 menjelaskan bahwa reduksi data, sajian data, dan verifikasi saling bertautan sebagai proses yang dilakukan pada waktu pengumpulan data sudah berakhir dan dilanjutkan sampai pada waktu penulisan berakhir.

\section{HASIL DAN PEMBAHASAN}

\section{Sekolah Keluarga dan Komunitas Belajar Salam}

Fokus tentang sekolah keluarga di Salam, menarik perhatian penulis pada pertengahan tahun 2019, saat penulis mendampingi mahasiswa untuk magang di Salam mulai bulan pertengahan Juli sampai akhir September. Memasuki tahun 2020 Salam telah memasuki dua dasawarsa dalam menyelenggarakan pendidikan anak usia dini dan pendidikan kesetaraan bagi masyarakat sekitar Nitiprayan. Salam meyakini bahwa penyelenggaraan pendidikan memerlukan proses belajar yang bersifat holistik. Kondisi ini dapat tercapai jika terbangun relasi antara sekolah, guru sebagai fasilitator, orangtua dan lingkungan sosialnya. Dengan demikian proses belajar menjadi gerakan untuk menemukan dan memahami hakikat nilai-nilai kehidupan. Bagi Salam, inilah hakikat sekolah kehidupan, yaitu menciptakan proses pendidikan yang dibangun atas dasar kebutuhan bersama dan menjadi kesepakatan bersama seluruh warga belajar.

Pedoman pendidikan bagi Salam adalah meletakkan sistem berfikir dan sikap positif yang dibangun sejak usia dini agar dapat memahami potensi dan problematika serta realitas kehidupan yang menjadi bekal di masa mendatang. Oleh karena itu, Salam menciptakan ruang untuk melakukan eksperimen dan eksplorasi bagi anak didik dengan memanfaatkan lingkungan sekitar sebagai media belajar. Filosofi pendidikan Salam memegang teguh nilai, mendengar, saya lupa; melihat, saya ingat; melakukan, saya paham; menemukan sendiri, saya kuasai (Batawy, 2018). 
Pada satu kesempatan wawancara dengan Bu Wahya dan penulis di meja yang berdampingan dengan etalase untuk menjual produk-produk Salam berbahan herbal seperti sabun dan madu, Bu Wahya bercerita bahwa Kelompok Bermain Salam pada awalnya diselenggarakan di rumah Ibu Wahya pada tahun 2004. Guru adalah fasilitator yang direkrut dari komunitas Salam dengan berbagai latar belakang pendidikan. Bu Wahya menjelaskan bahwa konsep sekolah keluarga diambil dari gagasan Ki Hajar Dewantara. Menurutnya bahwa pendidikan anak dimulai dari keluarga sebagai pendidik yang pertama dan utama. Sehingga orangtua juga harus teredukasi untuk mengikuti proses pembelajaran anak. Untuk menjadi anak didik di KB Salam, orangtua harus mengikuti dialog dengan sekolah untuk menyepakati berbagai persyaratan utama. Dukungan orangtua terhadap pendidikan anak diwujudkan dengan dibentuknya Forum Orangtua Salam (ForSalam) untuk berbagi informasi dan komunikasi antara orangtua, fasilitator dan pengelola. Kegiatan ini dilakukan melalui media sosial baik grup whatsapp maupun web yang sudah dibuat Salam seperti nampak pada gambar berikut ini:

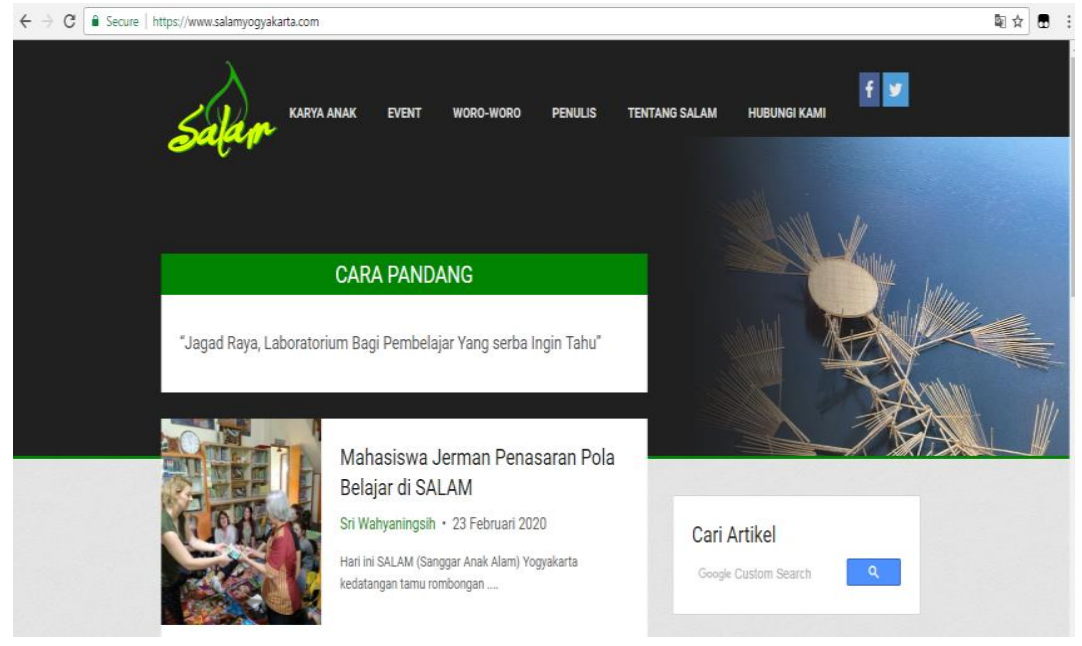

Gambar 2: Web Salam

Gambar 2 menunjukkan bahwa komunikasi yang dibangun oleh Salam dan lingkungan sosialnya bersifat interaktif. Berbagai konten yang mengangkat isu pendidikan menjadikan berbagai unsur di Salam memiliki ikatan sosial dan emosinal. Dukungan For Salam untuk sekolah berupa bantuan materi, ide, dan jasa bertujuan untuk memberikan ruang bagi orangtua melakukan diskusi dan koordinasi dalam kegiatan belajar anak di sekolah. Bentuk peran keluarga yang terlibat langsung adalah home visit, kegiatan pembelajaran di luar Salam ketika saat dilakukannya kunjungan, mini trip, field trip, dan cooking class.

Pada setiap awal semester, proses pembelajaran di Salam selalu menyelenggarakan workshop fasilitator. Dalam kegiatan ini fasilitator merumuskan tema besar yang kemudian didiskusikan bersama orangtua sekaligus menyepakati sistem pembelajaran. Kesepakatan bersama yang dibuat selama proses pembelajaran adalah menerapkan konsep jaga diri, jaga teman, dan jaga lingkungan. Demikian halnya pada kelompok KB Salam, setelah fasilitator menetapkan tema besar di awal semester, orangtua diundang agar menyesuaikan karakteristik anak dengan tema tersebut.

Komunikasi orangtua dan fasilitator masih berlanjut ketika para orang tua berkumpul untuk menunggu anaknya sekolah, melalui whatsapps maupun pertemuan yang sudah dijadwalkan bersama. Komunikasi ini memudahkan fasilitator untuk mengenal anak dan lebih mudah dalam mengembangkan karakter anak. Apabila ada kegiatan di luar kelas maka orangtua diajak berdiskusi untuk perencanaan dan pelaksanaan kegiatan. Fasilitator membuat perencanaan belajar dalam satu minggu berdasarkan masukan orangtua dan kembali didiskusikan bersama pada pertemuan yang diadakan setiap haris Kamis, seperti contoh dibawah ini: 
Tabel 1. Contoh Perencanaan Belajar dalam Satu Minggu Di KB Salam

Tema $\quad:$ Kebutuhanku

Sub Tema : : Kebersihan dan Kesehatan

\begin{tabular}{|c|c|c|c|c|c|c|}
\hline $\begin{array}{c}\text { Hari/ } \\
\text { Tanggal }\end{array}$ & $\begin{array}{c}\text { Aspek } \\
\text { Perkemba- } \\
\text { ngan }\end{array}$ & $\begin{array}{c}\text { Kompetensi } \\
\text { Dasar }\end{array}$ & Kegiatan & Metode & Media & Tujuan \\
\hline Senin & Bahasa & $\begin{array}{l}\text { Menunjukkan } \\
\text { kemampuan } \\
\text { berbahasa } \\
\text { secara } \\
\text { sederhana } \\
\text { (verbal dan non } \\
\text { verbal) }\end{array}$ & $\begin{array}{l}\text { - Story } \\
\text { Telling } \\
\text { monster } \\
\text { sampah } \\
\text { - Membuat } \\
\text { origami } \\
\text { sampah }\end{array}$ & $\begin{array}{l}\text { - Bercakap- } \\
\text { cakap } \\
\text { - Tanya } \\
\text { jawab } \\
\text { - Pemberian } \\
\text { tugas }\end{array}$ & $\begin{array}{l}\text { - Buku cerita } \\
\text { - Kertas lipat }\end{array}$ & \\
\hline Selasa & Seni & $\begin{array}{l}\text { Mencerminkan } \\
\text { perilaku yang } \\
\text { mencerminkan } \\
\text { sikap estetis }\end{array}$ & $\begin{array}{l}\text { - Bernyanyi } \\
\text { dan } \\
\text { berekspresi } \\
\text { sambil } \\
\text { mengikuti } \\
\text { musik } \\
\text { - Cerita } \\
\text { dengan } \\
\text { papan flanel } \\
\text { - Mengukur, } \\
\text { menimbang } \\
\text { berat badan }\end{array}$ & $\begin{array}{l}\text { - Praktek } \\
\text { langsung } \\
\text { - Bercakap- } \\
\text { cakap }\end{array}$ & $\begin{array}{l}\text { - Timbangan } \\
\text { - Pengukur }\end{array}$ & \\
\hline Rabu & Kognitif & $\begin{array}{l}\text { - Memiliki } \\
\text { perilaku yang } \\
\text { mencerminkan } \\
\text { sikap ingin tahu } \\
\text { - Mengenal } \\
\text { benda-benda di } \\
\text { sekitarnya } \\
\text { (warna, bentuk, } \\
\text { ukuran, rasa } \\
\text { dsb) }\end{array}$ & $\begin{array}{l}\text { - Kerja bakti } \\
\text { di sekitar } \\
\text { sekolah } \\
\text { - Mengubur } \\
\text { sampah } \\
\text { organik dan } \\
\text { non organik } \\
\text { secara } \\
\text { terpisah }\end{array}$ & $\begin{array}{l}\text { - Demons- } \\
\text { trasi } \\
\text { - Pemberian } \\
\text { tugas }\end{array}$ & $\begin{array}{l}\text { - Bambu } \\
\text { untuk } \\
\text { mengambil } \\
\text { sampah } \\
\text { - Plastik } \\
\text { untuk } \\
\text { tempat } \\
\text { sampah }\end{array}$ & \\
\hline \multirow[t]{3}{*}{ Kamis } & $\begin{array}{l}\text { Pembiasaan } \\
\text { moral }\end{array}$ & $\begin{array}{l}\text { Menghargai diri } \\
\text { sendiri, orang } \\
\text { lain, lingkungan } \\
\text { sekitar sebagai } \\
\text { rasa syukur } \\
\text { kepada Tuhan } \\
\text { YME }\end{array}$ & $\begin{array}{l}\text { - Bercakap- } \\
\text { cakap } \\
\text { tentang } \\
\text { kesehatan. } \\
\text { - Gosok gigi }\end{array}$ & $\begin{array}{l}\text { Demons- } \\
\text { trasi }\end{array}$ & $\begin{array}{l}\text { - Sikat gigi. } \\
\text { - Pasta gigi. }\end{array}$ & \\
\hline & & $\begin{array}{l}\text { Memiliki } \\
\text { perilaku yang } \\
\text { mencerminkan } \\
\text { sikap hidup } \\
\text { sehat }\end{array}$ & $\begin{array}{l}\text { Game } \\
\text { Engklek }\end{array}$ & $\begin{array}{l}\text { - Demons- } \\
\text { trasi } \\
\text { - Praktek }\end{array}$ & Bakiak & \\
\hline & & Fill Trip Pasty & giatan bersa & keluarga) & & \\
\hline
\end{tabular}

Tabel 1 merupakan salah satu contoh perencanaan pembelajaran yang dibuat dalam satu minggu oleh fasilitator. Yang berbeda dengan perencanaan pembelajaran pada umumnya, bahwa di KB Salam setiap hari Jum'at terdapat jadwal yang khusus melibatkan keluarga untuk terlibat langsung dalam proses pembelajaran di kelas bersama fasiltator dan anak didik. Pengembangan karakter anak usia dini yang terintegrasi dengan proses pembelajaran di KB Salam dengan menerapkan prinsip olah rasa (perasaan), olah pikir (pengetahuan) dan olah raga (perilaku) sebagaimana penjelasan berikut. Olah rasa adalah upaya untuk mengontrol emosi, perasaan dan membangun kejujuran. Setiap hari Selasa di KB 
Salam kegiatan pembelajaran difokuskan untuk mendorong anak didik untuk dapat menyanyi dan menari. KB Salam memberikan ruang agar anak dapat mengolah perasaaan gembira selama proses pembelajaran berlangsung. Fasilitator di KB Salam memproses anak mulai menyadarkan untuk menghargai, memberi, meminta maaf, berterimakasih meski terkadang anak dalam kondisi marah. Jika terjadi konflik antar anak didik, fasilitator menanyakan penyebab pertengkaran, sabar untuk untuk mendegarkan semua ungkapan anak didik, menanyakan alasannya dengan tujuan siswa perlu dihargai. Anak didik adalah obyek dan bukan subyek, sehingga mereka mampu memecahkan masalah, beretika, mempunyai harga diri, tidak malu dan berani bertanya.
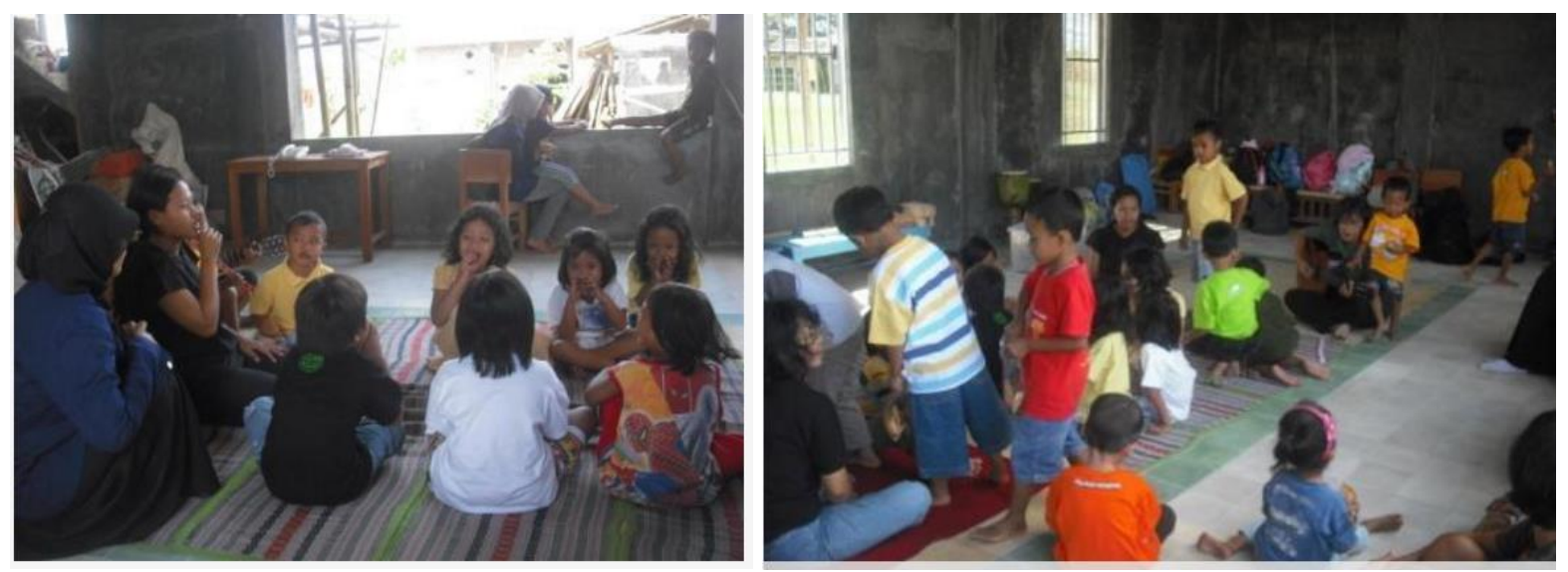

Gambar 3: Proses Pembelajaran di KB Salam

Gambar 3 menunjukkan proses pembelajaran di KB Salam yang menekankan pada prinsip olah pikir, olah rasa dan olah raga. Olah pikir bagi anak didik di KB Salam menekankan pada perkembangan kercerdasan anak yang diperoleh melalui pengamatan langsung. Daur belajar yang menjadi pendekatan pembelajaran di Salam mendorong anak didik untuk berproses melalui lima tahapan yaitu rencanakan, lakukan, ungkapkan, analisis dan kesimpulan. Pada KB Salam prinsip tersebut dijalankan sesuai dengan karakteristik anak usia dini. Peran fasilitator aktif memberikan pertanyaan sebagai stimulus yang mendorong anak didik menemukan sendiri jawabannya secara tidak langsung. Kreativitas anak untuk mengembangkan kosakata, wawasan, dan pengetahuan melalui berbagai sumber belajar berkorelasi dengan bertambahnya pengetahuan sebagai hasil interaksi dan pengamatan secara langsung.

Olah raga bagi anak didik di Salam berhubungan dengan keadaan fisik (raga), tingkah laku, karsa atau kemauan anak dalam bertindak sehingga mendorong anak untuk melakukan kebaikan. Kegiatan bermain yang menjadi kebutuhan anak usia dini diberikan sesuai dengan keinginan anak. Kegiatan ini pada KB Salam diterapkan baik di dalam kelas maupun luar kelas. Berbagai jenis permainan yang sudah disediakan di dalam kelas adalah permainan memasak, boneka, menempel, dan mewarnai. Sementara itu, lokasi Salam yang berada di persawahan menjadikan siswa KB Salam memanfaatkan saluran air dan sawah yang baru dipanen sebagai area bermain. Halaman yang tidak luas, digunakan anak didik untuk berkejar-kejaran atau bermain bola. Fasilitator memperbolehkan anak bermain asalkan memegang prinsip jaga diri, jaga teman, dan jaga lingkungan yang bisa meminimalisir konflik diantara mereka. Mereka didorong untuk menemukan pembelajaran di setiap mereka bermain agar anak menemukan sendiri apa yang harus diperbuat.

Asesmen yang dilakukan fasilitator dengan melakukan pencatatan setiap perkembangan dan pengalaman yang terjadi pada anak, seperti contoh di bawah ini: 
Tabel 2: Contoh Catatan Perkembangan Anak di KB Salam

\begin{tabular}{|c|c|c|}
\hline Hari/Tanggal & $\begin{array}{l}\text { Aspek } \\
\text { (sosialisasi, komunikasi dan ekspresi) }\end{array}$ & Keterangan \\
\hline $3 / 10 / 2017$ & $\begin{array}{l}\text { Alif aktif bertanya saat berpetualang. } \\
\text { Misalnya, melihat jalan yang rusak dan } \\
\text { melihat lubang di sawah }\end{array}$ & $\begin{array}{l}\text { Alif masih takut melewati } \\
\text { lubang di pematang sawah }\end{array}$ \\
\hline $4 / 10 / 2017$ & $\begin{array}{l}\text { Alif datang terus meminta ewer-ewer. } \\
\text { Ternyata alif minta kain kepunyaan laras } \\
\text { untuk sayap superman. Kemudian alif } \\
\text { memperagakan gerakan terbangnya. }\end{array}$ & Membuat sayap superman \\
\hline 9/10/2017 & $\begin{array}{l}\text { Alif masih sulit untuk bersepakat. Hari ini } \\
\text { alif pinjam mainan milik laras tapi sulit } \\
\text { untuk mengembalikan. Ibunya } \\
\text { menghampiri dan meminta dia } \\
\text { mengembalikan. }\end{array}$ & $\begin{array}{l}\text { Alif senang bermain kejar- } \\
\text { kejaran }\end{array}$ \\
\hline
\end{tabular}

Tabel 2 menunjukkan bahwa fasilitator menggunakan buku catatan setiap anak didik dan orangtua dapat bertanya setiap saat tentang perkembangan anaknya di sekolah. Komunikasi seperti ini dirasakan bermanfaat bagi orangtua untuk melihat perkembangan karakter anak baik psikologis maupun sosial. Fasilitator di KB Salam melaporkan hasil belajar anak di akhir semester secara naratif dan mengacu pada empak aspek perkembangan yaitu sikap, pengetahuan, ketrampilan dan minat siswa. Salam menerapkan evaluasi pembelajaran dengan merekam perkembangan anak, bukan menilai tetapi melihat proses. Sejak dini anak didik dilatih bekerjasama, bertanggugjawab dan saling menghormati.

Kemitraan di Salam.

Pada skala yang lebih luas, Salam memiliki kegiatan bernama Pasar Simbok yang menjadi ajang pertemuan rutin antara orangtua, anak didik dan masyarakat sekitar Salam. Kegiatan yang diinisiasi ForSalam ini adalah kerja kolektif dan bertujuan untuk membantu meringankan pendanaan Salam. Orangtua dan anak didik Salam terlibat dalam kegiatan apresiasi ini dengan cara kreatif dan sehat.
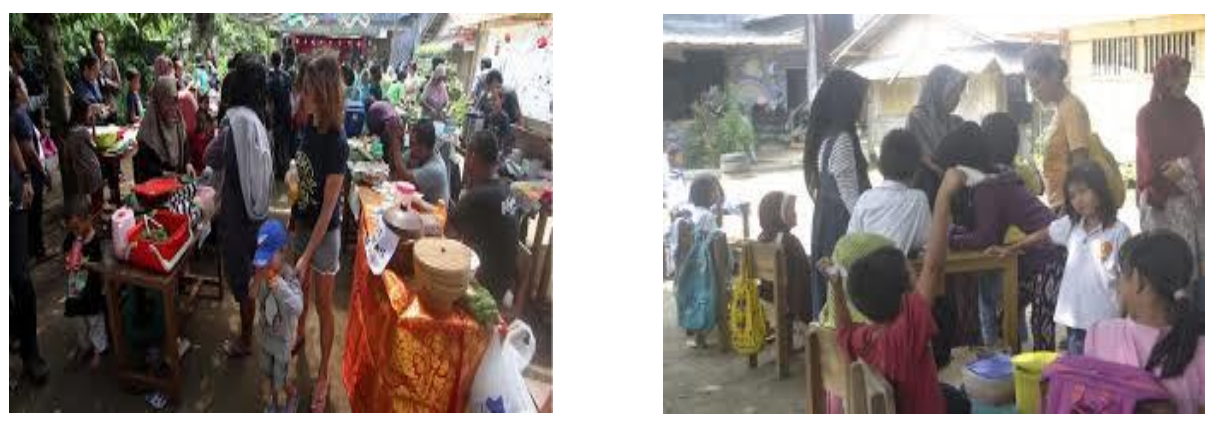

Gambar 4. Kegiatan Pasar Simbok di Salam

Gambar 4 menggambarkan kegiatan rutin Pasar Simbok sebagai kegiatan yang tidak hanya dihadiri para anak didik dan orangtua, namun juga masyarakat sekitar. Dalam acara tersebut ditampilkan berbagai karya seni anak didik mulai dari kelompok bermain hingga sekolah menengah atas. Selain itu, ada juga stand-stand menarik yang menjajakan makanan tradisional dan sehat oleh orangtua dan anak-anak. Kegiatan ini diadakan setiap 35 hari sekali sebagai sarana pembelajaran agar anak didik memahami pasar sebagai ruang aktualisasi diri.

Kegiatan Salam bersama ForSalam juga dikemas dalam bentuk bedah buku (Titi, 2017). Contoh kegiatan yang sudah diselenggarakan di Salam ketika mengundang Fawaz Al Batawy, seorang pengarang buku berjudul Yang Menyublim di Sela Hujan. Fawaz berkisah tentang anak-anak yang hidup di masyarakat adat Mumugu Batas Batu Distrik Sawaerma, 
Kabupaten Asmat, Papua. Anak-anak di daerah ini, menurut Fawaz, tidak siap dengan tradisi 'tanam pantat' di bangku sekolah. Fasilitator, orangtua dan anak didik Salam yang hadir sore itu seolah mendapat dikusi baru untuk mendefinisikan anak-anak Salam yang gemar sekali belajar di tempat-tempat yang tidak sewajarnya seperti memanjat pohon atau duduk di tepi parit.

Pengalaman Fawaz yang mendampingi anak-anak belajar, menegaskan bahwa pendekatan pembelajaran dan asesmen yang tepat adalah kunci keberhasilan belajar. Asesmen menjadi jembatan yang terus menerus dibangun, diperbaiki, dan dipertahankan. Satu pesan kuat yang disampaikan dalam kegiatan ini adalah menghindari arus berfikir yang bersifat menghakimi atas apapun yang tidak sama dengan kita. Baik itu cara hidup, cara berpikir maupun cara berperilaku. Sekolah menjadi sebuah konsep pembelajaran yang harus bersifat cair dan dapat berlangsung di mana saja.

Pada level nasional, Salam menginisiasi kegiatan workshop dan mengundang mereka untuk datang ke Salam. Mereka adalah mahasiswa, praktisi pendidikan, bahkan tamu awam yang ingin mengetahui tentang proses belajar di Salam. Mereka bertanya tentang proses belajar, pendanaan dan pengelolaan. Pertama kali Salam menyelenggarakan workshop secara terbuka pada awal tahun 2017 dan berikutnya minggu kedua bulan november masih di tahun yang sama. Pada tahun 2018 dan 2019 workshop diselenggarakan pada akhir bulan September. Adapun materi workshop meliputi paradigma berpikir, metodologi, hingga praktek langsung menyusun kurikulum secara mandiri dan merdeka.

Materi workshop yang disusun dapat digunakan sebagai bekal penyelenggaraan lembaga pendidikan non formal. Workshop diselenggarakan dengan jumlah peserta sebanyak 20 orang demi mengoptimalkan capaian pembelajaran. Fasilitator, wali murid dan anak didik juga ikut dalam pertemuan ini untuk berbagi pengalaman belajar. Prinsip Salam bahwa belajar harus dekat dengan kehidupan sosial menjadi agenda rutin yang dikemas melalui berbagai kegiatan.

Salam mengembangkan ekologi belajar dan membangun kemitraan yang melibatkan anak didik, orangtua, guru, staf, penduduk setempat, kalangan pengusaha, dan organisasiorganisasi lokal maupun nasional dalam jaringan sosial yang dalam rangka peningkatan mutu pendidikan (Marzuki \& Syamsuardi, 2018: 43-47). Prinsip bahwa orangtua, anak didik dan fasilitator harus belajar bersama telah membentuk komunitas belajar yang dibangun atas dasar kebutuhan dan kesepakatan bersama seluruh warga belajar. Komunitas belajar yang terdiri dari keluarga, sekolah, masyarakat dan pihak eksternal adalah sistem untuk menjalankan fungsi mekanisme kontrol dalam kegiatan proses belajar, sebagaimana dapat dilihat pada skema berikut ini.

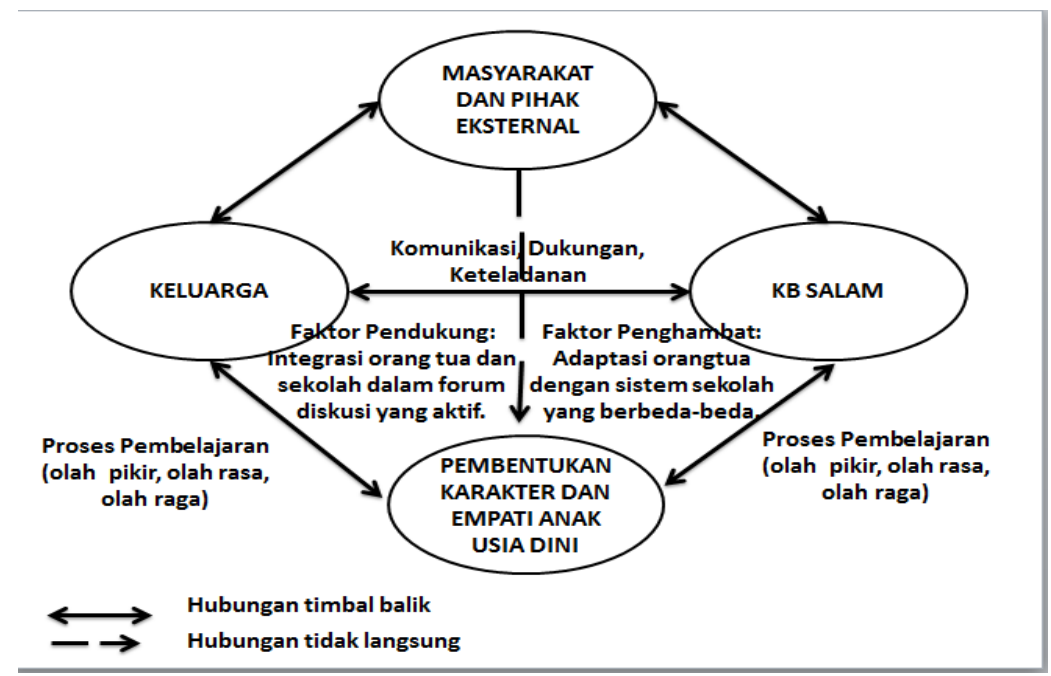

Gambar 5. Sekolah keluarga dalam pembentukan kreativitas dan empati di Salam 
Gambar 5 mendeskripsikan penerapan sekolah keluarga dalam pembentukan krestivitas dan empati, yang membutuhkan kerjasama pihak-pihak utama dan perlunya indikator yang harus ada agar dapat terselenggara dengan baik. Pihak yang utama adalah KB Salam, anak didik, keluarga dan masyarakat. Sedangkan indikator utama yang dibutuhkan adanya komunikasi dan keteladanan yang hadir dalam proses pembelajaran yang melibatkan olah pikir, olah rasa, dan olah raga. Konsep sekolah keluarga di Salam menerapkan prinsip: 1) komunikasi sebagai ruang berbagi informasi dan konsultasi antara guru dan orangtua dalam pembentukan karakter anak didik; 2) dukungan kerjasama untuk mempermudah dalam pelaksanaan proses belajar siswa; 3) keteladanan sebagai cermin bagi anak didik dalam melakukan pembiasaan untuk pembentukan karakter nilai, agama, sosial dan budaya. Kohesi sosial melalui upaya komunikasi, dukungan dan keteladanan telah menyelaraskan hubungan antara orang tua dan sekolah dalam pembentukan kreativitas dan empati anak usia dini. KB Salam adalah ruang bagi anak usia dini dalam proses pembentukan karakter yang menerapkan pikiran Ki Hajar Dewantara tentang olah rasa, olah pikir dan olah (Dewantara K. H., 2011: 67-100). Olah rasa sebagai bentuk upaya anak mengontrol emosi, perasaan dan dapat membangun kejujuran sehingga dapat memelihara keimanan dan spiritual dalam keseharian anak. KB Salam memberikan ruang untuk anak mengolah perasaan gembira dengan pembelajaran menyanyi dan menari yang dilakukan bersama orangtua dan diiringi musik pada setiap haris Selasa. Olah pikir, bertugas untuk mencari kebenaran dari hasil membandingkan barang atau keadaan antara yang satu dengan lainnya. Penerapan metode daur belajar di KB Salam mendorong perkembangan kecerdasan anak didik secara alamiah. Anak didik bebas mengeksplorasi pengetahuan dengan bantuan guru sebagai fasilitator. Olah raga, adalah kondisi yang berkaitan dengan fisik, tingkah laku dan kemauan anak dalam bertindak dan berperilaku postif. Di KB Salam peran fasilitator untuk memotivasi anak didik menjadi faktor yang menentukan agar mereka mampu menuangkan perasaan dan pikirannya untuk melahirkan sikap positif.

Menurut Nan Lin sebagaimana dikutip Dwiningrum, Salam telah memenuhi dua fitur kebutuhan keluarga dalam memenuhi kebutuhan pendidikan anaknya, yaitu: 1) sumber daya yang dapat diakses melalui hubungan langsung dan tidak langsung, 2) sumber daya seperti harta atau posisi sosial guna mengakses ikatan sosial yang permanen (Dwiningrum, 2014: 78). Sama seperti pandangan Nan Lin, Acar menjelaskan pengaruh modal sosial dalam aspek pengembangan akademik. Modal sosial yang dimaksud adalah hubungan dan jaringan sosial, informasi, kepercayaan, dan hubungan timbal balik yang mempermudah individu ataupun antar anggota kelompok dalam menyelesaikan persoalan yang dihadapinya. Acar memberi contoh berbagai masalah dilingkungan sekolah, termasuk infrastruktur pendidikan, maintanance, keamanan dan promosi sekolah dapat diselesaikan dengan mudah dan efektif jika menggunakan jaringan orang tua. Ikatan dan hubungan yang dimiliki oleh orang tua anak didik merupakan modal sosial yang mempermudah dalam mencapai tujuan-tujuan yang diharapkan (Acar, 2011: 461).

Ikatan yang kuat antara sekolah dan keluarga menjadikan anak usia dini memiliki rasa nyaman untuk berkembang sesuai dengan karakteristiknya. Perspektif ini sejalan dengan pendapat Boonk bahwa keluarga dan KB di Salam telah berperan sebagai mediator dan moderator dan berkorelasi terhadap perkembangan akademik anak (Boonk, Gijselaers, \& Brand-Gruwel, 2018: 30). Bagi Salam kreativitas dan empati adalah bagian dari karekteristik anak usia dini yang penting untuk mendorong perkembangan akademik ini. Interkonektivitas antara guru, orangtua dan anak didik yang bersifat horisontal telah berfungsi menggarap tiga ranah kepribadian manusia seperti pendapat Benjamin Bloom, yaitu affective domain, cognitive domain dan psychomotoric atau conative domain (Topatimasang, 2013; 104)

Prinsip pendidikan di Salam dengan tujuan untuk meletakkan sistem berfikir dan sikap yang dibangun sejak dini, memposisikan guru adalah fasilitator yang berperan sebagai katalisator, inspirator, dinamisator dan evaluator dalam pengembangan karakter anak usia dini. Sebagai katalisator, fasilitator di KB Salam memberikan teladan untuk meletakkan dasar etika sebagai sosok yang disegani dan dihormati oleh anak didik. Peran sebagai inspirator, 
DOI: 10.31004/obsesi.v5i1.665

mendorong fasilitator untuk membangkitkan semangat anak didik untuk mengembangkan potensinya. Peran sebagai administrator, bermakna bahwa fasilitator di KB Salam mendorong kemampuan anak didik sesuai bakat dan kemampuannya. Peran sebagai evaluator, fasilitator di KB Salam mengevaluasi perilaku anak didik maupun metode pembelajaran selama proses pembelajaran. (Saleh, 2012: 18).

KB Salam menerapkan Kurikulum 2013 Pendidikan Anak Usia Dini yang sudah diintegrasikan dengan visi dan misi pendidikan di Salam. Hanya saja Salam memberikan istilah empak aspek perkembangan yaitu sikap, pengetahuan, ketrampilan dan minat siswa. Pertama, Salam mengoptimalkan enam perkembangan anak yaitu: nilai agama dan moral, fisik-motorik, kognitif, bahasa, sosial emosional, dan seni. Kedua, menggunakan pembelajaran tematik dengan pendekatan saintifik dalam pemberian rangsangan pendidikan. Pada aspek ini KB Salam menggunakan tema berdasarkan minat anak didik. Ketiga, menggunakan penilaian otentik dalam memantau perkembangan anak. KB Salam menggunakan prinsip asesmen berdasarkan buku catatan dan portofolio yang dibuat fasilitator. Keempat, memberdayakan peran orang tua dalam proses pembelajaran. KB Salam membuat kelompok bagi orangtua yang berperan baik pada skala lokal maupun nasional. Proses pembelajaran di KB Salam telah menerapkan parents gathering, foundation class, seminar , hari konsultasi, field trip, home activities, cooking on the spot, bazar day, home education sebagai upaya peningkatan wawasan dan membantu dalam proses pendampingan tumbuh kembang anak (Kurniawan \& Hermawan, 2017: 29-39).

Uraian diatas menggiring pada paparan yang menegaskan bahwa Salam menyelenggarakan pendidikan berbasis masyarakat dengan menggunakan model layanan langsung (direct service model). Beberapa karakteristik dasar yang sudah dipenuhi oleh Salam adalah; pertama, Salam memiliki otoritas otonom dalam mengatur penyelenggaraan pendidikan. Kedua, membangun partisipasi masyarakat dalam penyelenggaraan pendidikan mulai tingkat lokal dan nasional. Ketiga, Salam menekankan pada upaya transformatif dan pemberdayaan masyarakat dalam segenap aspek kehidupan. Keempat, Salam mendayagunakan segenap potensi sumber daya yang ada di masyarakat dalam penyelenggaraan pendidikan. Kelima, Salam menggunakan kurikulum dan pembelajaran yang disusun berdasarkan karakteristik dan kebutuhan masyarakat. Keenam, Salam menggunakan pendekatan orang dewasa (andragogi) dalam proses pembelajaran. Ketujuh, Salam memposisikan pemerintah sebagai fasilitator (Fuad, 2014: 68). Penyelenggaraan sekolah di Salam dengan menggandeng keluarga, menjadikan anak didik tidak mengalami ketercerabutan budaya tetapi justru mengalami culturally overwhelmed dan melahirkan culturebound (Spradley, 2007: 17). Kondisi ini telah menciptakan lingkungan sosial yang berpengaruh pada berlangsungnya pendidikan karakter yang bermanfaat bagi tumbuh kembang anak didik di KB Salam yaitu kreativitas dan empati, selain perkembangan kognitif anak usia dini.

\section{SIMPULAN}

Pembelajaran di KB Salam didesain tidak menggunakan konsep pembelajaran dengan menggunakan penelitian tindakan kelas seperti pada umumnya, tetapi menciptakan habitus komunitas belajar dengan cara pendayagunaan metode pembelajaran yang bersinergi dengan interaksi sosial antara guru, anak didik dan orangtua. Hal ini di diwujudkan dengan mengembangkan kurikulum pembelajaran berdimensi lokal, namun tetap mengacu pada kurikulum pada dinas pendidikan, dengan pertimbangan dasar filosofi dan konteks sosial. Interkonektivitas sekolah, orangtua dan anak didik adalah wujud sekolah keluarga dan menjadi modal sosial untuk mengembangkan karakteristik anak usia dini yang tidak didominasi oleh perkembangan kognitif saja, namun juga perkembangan empati dan kreativitas. 


\section{DAFTAR PUSTAKA}

Aasheim, M., Drugli, M. B., Reedtz, C., Handegard, B. H., \& Martinussen, M. (2018). Change in teacher-student relationships and parent involvement after implementation of the Incredible Years Teacher Classroom Management programme in a regular Norwegian school setting. Educational Research Journal, 44(6), 1064-1083. https:// doi.org/10.1002/berj.3479

Acar, E. (2011). Effect of Social Capital on Academic Succes : A Narative Synthesis. Educational Research and Review, 6(6), 456-461. https:// academicjournals.org/journal/ERR/articleabstract/8BD71B95320

Akhyadi, A., \& Mulyono, D. (2019). Program Parenting dalam Meningkatkan Kualitas $\begin{array}{llll}\text { Pendidikan Keluarga. } \quad \text { Abdimas } & \text { 1-8. }\end{array}$ http://dx.doi.org/10.22460/as.v1i1p1-8.34

Ananda, R., \& Fadhilaturrahmi, F. (2018). Peningkatan Kemampuan Sosial Emosional Melalui Permainan Kolaboratif pada Anak KB. Jurnal Obsesi: Jurnal Pendidikan Anak Usia Dini, 2(1), 20-26. https:// doi.org/10.31004/obsesi.v2i1

Arifiyanti, N. (2015). Kerjasama Antara Sekolah Dan Orangtua Siswa Di TK Se-Kelurahan Triharjo Sleman. http://journal.student.uny.ac.id/ojs/ojs/index.php/pgpaud/article/view/350/317

Asmawati, L. (2017). Peningkatan Kreativitas Anak Usia Dini Melalui Pembelajaran Terpadu Berbasis Kecerdasan Jamak. Jurnal Pendidikan Usia Dini, 11(1), 145-164. https:// doi.org/10.21009/JPUD.111.10

Astuti, R., \& Aziz, T. (2019). Integrasi Pengembangan Kreativitas Anak Usia Dini di TK Kanisius Sorowajan Yogyakarta. Jurnal Obsesi: Jurnal Pendidikan Anak Usia Dini, 3(2), 294-302. https://doi.org/10.31004/obsesi.v3i2

Batawy, F. (2018). Memahami Pendidikan Alternatif Dari Sanggar Anak Alam (SALAM). Dipetik April 3, 2020, dari salamyogyakarta: https://www.salamyogyakarta.com/profil/

Boonk, L., Gijselaers, H., \& Brand-Gruwel, S. (2018). A review of the relationship between parental involvement indicators and academic achievement. Educational Research Review, 24, 10-30. https://doi.org/10.1016/j.edurev.2018.02.001

Debeturu, B., \& Wijayaningsih, E. (2019). Meningkatkan Kreativitas Anak Usia 5-6 Tahun melalui Media Magic Puffer Ball. Jurnal Obsesi: Jurnal Pendidikan Anak Usia Dini, 3(1), 233-240. https://doi.org/10.31004/obsesi.v3i1

Desyanty, E. S. (2016). Kompetensi Orangtua dalam Penumbuhkembangan Jiwa Kewirausahaan pada Anak Usia Dini. Jurnal Al-Athfal: Jurnal Pendidikan Anak, 2(2), 6984. http:/ / ejournal.uin-suka.ac.id/tarbiyah/index.php/alathfal/article/view/1268

Dewantara, K. (2011). Karya Ki Hadjar Dewantara Bagian Pertama: Pendidikan. Yogyakarta: Yayasan Persatuan Taman Siswa.

Dimerman, S. (2009). Character is the Key: How to Unlock the Best in our Children and Our-selves. Mississauga, Canada: John wiley \& Sons Canada.

Dwiningrum, S. A. (2014). Modal Sosial dalam Pengembangan Pendidikan: Perspektif Teori dan Praktek. Yogyakarta: UNY Press.

Elvida, E. (2012). Peningkatan Kreativitas Anak dengan Menggunakan Bahan Sisa di Taman Kanak-Kanak Aisyiyah 2 Duri. Jurnal Ilmiah Pesona PAUD, 1(4)., 1-33. http://ejournal.unp.ac.id/index.php/paud/article/view/1680/1449

Epstein, J. L. (2018). School, family and community partnerships in teacher' profesional work. Journal of Education for Teaching, 1-11. https:// doi.org/10.1080/02607476.2018.1465669

Fuad, N. (2014). Manajemen Pendidikan Berbasis Masyarakat: Konsep dan Stratgei Implementasi. Depok: PT Rajagrafindo Persada.

Garzia, M., Yufiarti, Y., \& Hartati, S. (2019). Perbedaan Kesiapan Sekolah Anak Usia Dini di Daerah Pesisir Ditinjau dari Status Ekonomi Orang Tua dan Parenting. Jurnal Obsesi: Jurnal Pendidikan Anak Usia Dini, 3(2), 470-483. https:/ / doi.org/10.31004/obsesi.v3i2 
DOI: 10.31004/obsesi.v5i1.665

Iis, N. (2012). Pengembangan Empati Anak Usia Dini Melalui Mendongeng di Taman KanakKanak Asyiyah Pariaman. Jurnal Ilmiah Pesona PAUD, 1(4)., 1-11. http://ejournal.unp.ac.id/index.php/paud/article/view/1667

Irma, C., Nisa, K., \& Sururiyah, S. (2019). Keterlibatan Orang Tua dalam Pendidikan Anak Usia Dini di TK Masyithoh 1 Purworejo. Jurnal Obsesi: Jurnal Pendidikan Anak Usia Dini, 3(1), 214-224. https://doi.org/10.31004/obsesi.v3i1.152

Izza, H. (2020). Meningkatkan Perkembangan Sosial Anak Usia Dini melalui Metode Proyek. Jurnal Obsesi: Jurnal Pendidikan Anak Usia Dini, 4(2), 951-961. https://doi.org/10.31004/obsesi.v4i2.483

Kurniawan, H., \& Hermawan, R. (2017). Program Parenting untuk Membentuk Karakter Anak Usia Dini di Lembaga Pendidikan Anak Usia Dini. aș-șibyān: Jurnal Pendidikan Anak $\begin{array}{lll}\text { Usia Dini, 29-39. } & \end{array}$ http://www.jurnal.uinbanten.ac.id/index.php/assibyan/article/view/190

Machmud, H., Alim, N., \& Ulviya, L. (2020). Keterampilan Sosial Anak Suku Bajo di Sulawesi Tenggara. Jurnal Obsesi: Jurnal Pendidikan Anak Usia Dini, 4(2)., 787802. https://doi.org/10.31004/obsesi.v4i2.459

Mardliyah , S., Siahaan, H., \& Budirahayu, T. (2020: 892). Pengembangan Literasi Dini melalui Kerjasama Keluarga dan Sekolah di Taman Anak Sanggar Anak Alam Yogyakarta. , 892-899. Jurnal Obsesi: Jurnal Pendidikan Anak Usia Dini, 4(2), 892-899. https://doi.org/10.31004/obsesi.v4i2.476

Martinis, M. (2012). Peningkatan Kreativitas Anak melalui Melukis Menggunakan Sikat Gigi Taman Kanak-Kanak Padang. Jurnal Ilmiah Pesona PAUD, 1(4)., 1-11. http://103.216.87.80/index.php/paud/article/view/1677

Marzuki, K., \& Syamsuardi, S. (2018). Penyelenggaraan Parenting Ducation Dalam Mengembangkan Kemitraan Orangtua Dengan Lembaga Pendidikan Anak Usia Dini. In Prosiding Seminar Nasional \& Temu Kolegial Jurusan PLS Se-Indonesia (hal. 43-47). Makasar: Jurusan PLS FIP UNM. https://ojs.unm.ac.id/prosidingpls/article/view/10051

Maynard, A. S., Monk, J., \& Booker, K. (2011). Maynard, A. S., Monk, J. D., \& Booker, K. W. (2011). Building empathy through identification and expression of emotions: A review of interactive tools for children with social deficits. Journal of Creativity in Mental Health, 6(2),, 166-175.https:// doi.org/10.1080/15401383.2011.579874

Perdina, S., Safrina, R., \& Sumadi, T. (2019). Peningkatan Kemampuan Sosial melalui Bermain Kartu Estafet pada Anak Usia Dini. Jurnal Obsesi: Jurnal Pendidikan Anak Usia Dini, 3(2), 440-447. https://doi.org/10.31004/obsesi.v3i2

Prahesti, S., Taulany, H., \& Dewi, N. (2019). Gerak dan Lagu Neurokinestetik (GELATIK) untuk Menumbuhkan Kreativitas Seni Anak Usia Dini. Jurnal Obsesi: Jurnal Pendidikan Anak Usia Dini, 4(1),, 162-171. https:/ / doi.org/10.31004/obsesi.v4i1.289

Prentice, R. (2000). Creativity: a reaffirmation of its place in early childhood education. The Curriculum Journal, 11(2), 145-158. https://doi.org/10.1080/09585170050045173

Purnamasari, Y., \& Wuryandani, W. (2019). Media Pembelajaran Big Book Berbasis Cerita Rakyat untuk Meningkatkan Karakter Toleransi pada Anak Usia Dini. Jurnal Obsesi: Jurnal Pendidikan Anak Usia Dini, 4(1), 90-99. https:/ / doi.org/10.31004/obsesi.v4i1.273

Putri, L., Yetti, E., \& Hartati, S. (2020). Pengaruh Keterlibatan Orangtua dan Regulasi Diri terhadap Perilaku Bullying Anak Usia Dini. Jurnal Obsesi: Jurnal Pendidikan Anak Usia Dini, 4(2), 715-732. https:/ / doi.org/10.31004/obsesi.v4i2.438

Putro, K. Z. (2015). Pengaruh pola asuh dan interaksi teman sebaya terhadap kecerdasan emosional anak di Ra arif rahman hakim Yogyakarta. Jurnal Al-Athfal: Jurnal Pendidikan Anak, 1(2), 97-108. http://digilib.uinsuka.ac.id/24107/1/Khamim\%20Zarkasih\%20Putro\%20-

\%20Pengaruh\%20Pola\%20Asuh\%20Dan\%20Interaksi\%20Teman\%20Sebaya\%20Terha dap\%20Kecerdasan\%20Emosional\%20Anak\%20Di\%20Ra\%20Arif\%20Rahman $\% 20 \mathrm{Ha}$ kim\%20Yogyakarta.pdf 
Rachmawati, Y., \& Kurniati, E. (2010). Strategi Pengembangan Kreativitas pada Anak Usia Taman Kanak-Kanak. Jakarta: Kencana.

Rahman, U. (2009: 46). Karakteristik perkembangan anak usia dini. Lentera Pendidikan. Jurnal Ilmu Tarbiyah dan Keguruan, 12(1), 46-57. https:/ / doi.org/10.24252/1p.2009v12n1a4

Ramadhani, P., \& Fauziah, P. (2020). Hubungan Sebaya dan Permainan Tradisional pada Keterampilan Sosial dan Emosional Anak Usia Dini. Jurnal Obsesi: Jurnal Pendidikan Anak Usia Dini, 4(2), 1011-1020. https:/ / doi.org/10.31004/obsesi.v4i2.502

Richaud, M. C., Lemons, V. N., Mesurado, B., \& Oros, L. (2017). Construct validity and reliability of a new Spanish empathy questionnaire for children and early adolescents. Frontiers in psychology, 8, Article 979. https:/ / doi.org/10.3389/fpsyg.2017.00979

Robbiyah, R., Ekasari, D., \& Witarsa, R. (2018). Pengaruh Pola Asuh Ibu terhadap Kecerdasan Sosial Anak Usia Dini di TK Kenanga Kabupaten Bandung Barat. Jurnal Obsesi: Jurnal Pendidikan Anak Usia Dini, 2(1), 76-84. https:/ / doi.org/10.31004/obsesi.v2i1.10

Rozana, A. A., Wahid, A. H., \& Muali, C. (2018 ). Smart Parenting Demokratis Dalam Membangun Karakter Anak. Rozana, A. A., Wahid, A. H., \& Muali, C. (2018). SmarAlAthfal: Jurnal Pendidikan Anak, 4(1), 1-16. https://doi.org/10.14421/al-athfal.2018.41-01

Saleh, M. (2012). Peran Guru dalam Menanamkan Pendidikan Karakter Anak Usia Dini di Paud Se-Kecamatan Limboto. Jurnal Pedagogika, 3, 1-8. https:/ / repository.ung.ac.id/karyailmiah/show/170/peran-guru-dalammenanamkan-pendidikan-karakter-anak-usia-dini-di-paud-se-kecamatanlimboto.html

Sari, D., \& Nurjanah, A. (2020). Hubungan Game Online dengan Perkembangan Emosional Anak Usia 5-6 Tahun. 994-999. Jurnal Obsesi: Jurnal Pendidikan Anak Usia Dini, 4(2)., 994999. https://doi.org/10.31004/obsesi.v4i2.344

Sari, H., \& Nofriyanti, Y. (2019). Peningkatan Kreativitas Anak Usia Dini melalui Kegiatan Menganyam dengan Origami. Jurnal Obsesi: Jurnal Pendidikan Anak Usia Dini, 4(1), 146151. https://doi.org/10.31004/obsesi.v4i1.247

Sari, M., Yetti, E., \& Supena, A. (2019). Peningkatan Keterampilan Sosial melalui Kegiatan Tari Saman. Jurnal Obsesi: Jurnal Pendidikan Anak Usia Dini, 4(1), 1-9. https:// doi.org/10.31004/obsesi.v4i1.240

Spradley, J. (2007). Metode Wawancara. Yogyakarta: Tiara Wacana.

Subkhan, E. (2013). Toward Critical Educational Technology for Early Childhood Education. Indonesian Journal of Early Childhood Education Studies, 2(1)., 1-8. DOI 10.15294/IJECES.V2I1.9216

Sutopo, H. B. (2001). Metodologi Penelitian Kualitatif: Dasar Teori dan Terapannya dalam Penelitian. Surakarta: Sebelas Maret University Press.

Tatminingsih, S. (2019). Kemampuan Sosial Emosional Anak Usia Dini di Nusa Tenggara Barat. Jurnal Obsesi: Jurnal Pendidikan Anak Usia Dini, 3(2),, 484-493. https:// doi.org/10.31004/obsesi.v3i2.170

Titi, G. (2017). Sore Yang Tidak Hujan. Dipetik April 3, 2020, dari salamyogyakarta: https:/ / www.salamyogyakarta.com/sore-yang-tidak-hujan/

Topatimasang, R. (2013). Sekolah itu Candu. Yogyakarta: Insist Press.

Ulfah, M. (2019). Pendekatan Holistik Integratif Berbasis Penguatan Keluarga pada Pendidikan Anak Usia Dini Full Day. Jurnal Obsesi: Jurnal Pendidikan Anak Usia Dini, 4(1), 10-19. https://doi.org/10.31004/obsesi.v4i1.255

Wahyuningsih, S., Pudyaningtyas, A., Hafidah, R., Syamsuddin, M., Nurjanah, N., \& Rasmani, U. (2019). ). Efek Metode STEAM pada Kreatifitas Anak Usia 5-6 Tahun. Jurnal Obsesi: Jurnal Pendidikan Anak Usia Dini, 4(1), 295-301. https:// doi.org/10.31004/obsesi.v4i1.305

Wiyani, N. A. (2016). Konsep Dasar PAUD. Yogyakarta: Gavamedia.

Wright, S. (2010). Understanding Creativity in Early Childhood. SAGE. 